\title{
Density estimates of nine hornbill species in a lowland forest site in southern Thailand
}

\author{
GEORGE A. GALE and SIRIPORN THONGAREE
}

\section{Summary}

Hornbills are useful indicators of forest condition and human disturbance because they require large tracts of unfragmented forest with large fruiting trees for feeding and nesting. They are relatively large-bodied, which makes them targets for hunting. Density estimates of such species are critical for population monitoring and serve as a baseline against which future changes can be measured. In this study we used variable-width line transect surveys to estimate the densities of nine hornbill species in the Bala portion of the Hala-Bala Wildlife Sanctuary on the Thai-Malaysia border, one of the few remaining areas of lowland forest in Thailand. The hornbill species were: Rhinoceros (Buceros rhinoceros), Great (B. bicornis), Helmeted (B. vigil), Black (Anthracoceros malayanus), Bushy-crested (Anorrhinus galeritus), White-crowned (Aceros comatus), Wrinkled (A. corrugatus), Wreathed (A. undulatus) and Plain-pouched (A. subruficollis). Between January 2001 and April 2002, II transects along trails, old logging roads and one paved road were surveyed once per month. A total of 1,261 observations of the nine species were made during the observation period. Estimates for Rhinoceros and Helmeted Hornbill were 2.69 and 1.21 individuals $/ \mathrm{km}^{2}$, respectively, and were similar or slightly higher than densities reported elsewhere. Estimates for Great (0.12), Bushy-crested (0.64), Wrinkled (0.08), White-crowned (0.08) and Wreathed Hornbills (o.69) were generally lower than estimates from other areas in the region. It was not possible to obtain density estimates using distance sampling for Black and Plain-pouched Hornbills due to the small number of observations, but our data did suggest that their densities were also low $\left(<0.10\right.$ individuals $\left./ \mathrm{km}^{2}\right)$. Potential reasons for differences between this and other areas include a scarcity of lowland habitat, habitat isolation, lower abundance of specific fruit resources and interspecific competition, but these factors require further investigation. Standardization of survey techniques among studies would significantly improve assessments of habitat requirements as well as of the effects of human disturbance on Asian hornbills, most of which are globally threatened. Our study specifically underscores the need for additional research on the Plain-pouched Hornbill, the most threatened of the species studied, as density estimates from elsewhere in its range are lacking, while more generally it highlights the need to investigate the underlying causes of the often substantial variation in hornbill densities among species and sites.

\section{Introduction}

Relatively undisturbed lowland (<200 m elevation) forest is now rare in the Sundaic region (Lambert and Collar 2002), particularly in southern Thailand where more than $95 \%$ of the natural forest has been destroyed (Round 1988). Several species of birds are dependent on this habitat and have consequently become threatened due to this loss (Round 1988). Hornbills (family Bucerotidae) are particularly sensitive indicators of forest condition and human disturbance because they require large tracts of unfragmented forest with large fruiting trees for feeding and nesting, and, being 
large-bodied, are targets for hunting (Poonswad 1998, Lambert and Collar 2002). Although the presence or absence of hornbills is now fairly well documented for the remaining lowland forest and other forests of Thailand (Round 1988, Poonswad 1998, Robson 2002), density estimates generally have not been produced. For some species, such as the Plain-pouched Hornbill (Aceros subruficollis), listed as Vulnerable (IUCN 2004), almost no field data are available, while basic density data on even the Great Hornbill (Buceros bicornis), listed as Near Threatened (IUCN 2004) and the most widespread Asian species, are extremely limited, and are lacking entirely from the Sundaic region. Because we were interested in the long-term management of relatively rare or threatened species, unbiased estimates of density, which incorporate some estimate of detectability, are more valuable than presence/absence or relative abundance, as they are more likely to provide managers with comparable survey results over time or space, and thus more accurate assessments of habitat suitability relative to different levels of human disturbance (Karanth and Nichols 1998, Fancy and Sauer 2000, Norvell et al. 2003). Density estimates are therefore the starting point for monitoring populations and judging the success or failure of conservation and management actions. Here we estimated the densities of nine species of hornbills in a lowland forest of southern Thailand.

\section{Methods}

Focal species

We focused on nine species of hornbill, all of which are of international and/or national conservation concern: Plain-pouched (Aceros subruficollis) listed as Vulnerable (IUCN 2004); Rhinoceros (Buceros rhinoceros), Great (B. bicornis), Helmeted (B. vigil), Black (Anthracoceros malayanus), White-crowned (Aceros comatus), Wrinkled (A. corrugatus), all listed as Near Threatened (IUCN 2004); and Wreathed (A. undulatus) and Bushy-crested (Anorrhinus galeritus) unlisted internationally, but considered Near Threatened nationally (OEPP undated). The Wrinkled Hornbill (the rarest of the hornbills in Thailand) and Plain-pouched Hornbill were of particular concern because they are mainly restricted to level lowland or valley-bottom evergreen forest (Lekagul and Round 1991).

\section{Study area}

The Bala forest is part of the Hala-Bala Wildlife Sanctuary, on the Thai-Malaysia border $\left(5^{\circ} 37^{\prime} \mathrm{N}\right.$, $101^{\circ} 08^{\prime} \mathrm{E}$; Figure 1$)$. The Bala portion of the Sanctuary is $111.5 \mathrm{~km}^{2}$ in area and is isolated from other forests by agricultural lands on the Thai side of the border (the $314 \mathrm{~km}^{2}$ Hala portion of the Sanctuary lies approximately $22 \mathrm{~km}$ to the west) and a mix of forest and agriculture on the Malaysian side. Bala ranges in elevation from 50 to $960 \mathrm{~m}$ a.s.l. and is broadly classified as tropical lowland evergreen forest. Average rainfall is generally heavy and during the first year of the study (2001) was $>4,700 \mathrm{~mm}$. During 1987-1992 Bala was partly logged along the paved road that bisects the lower one-third of the site, and sporadically (and illegally) logged elsewhere in the sanctuary. However, with the nine species of hornbills or approximately $29 \%$ of the currently recognized Asian hornbills present at the site (Kemp 1995), it is still one of richest in the region (M. Kinnaird in litt. 2003). 


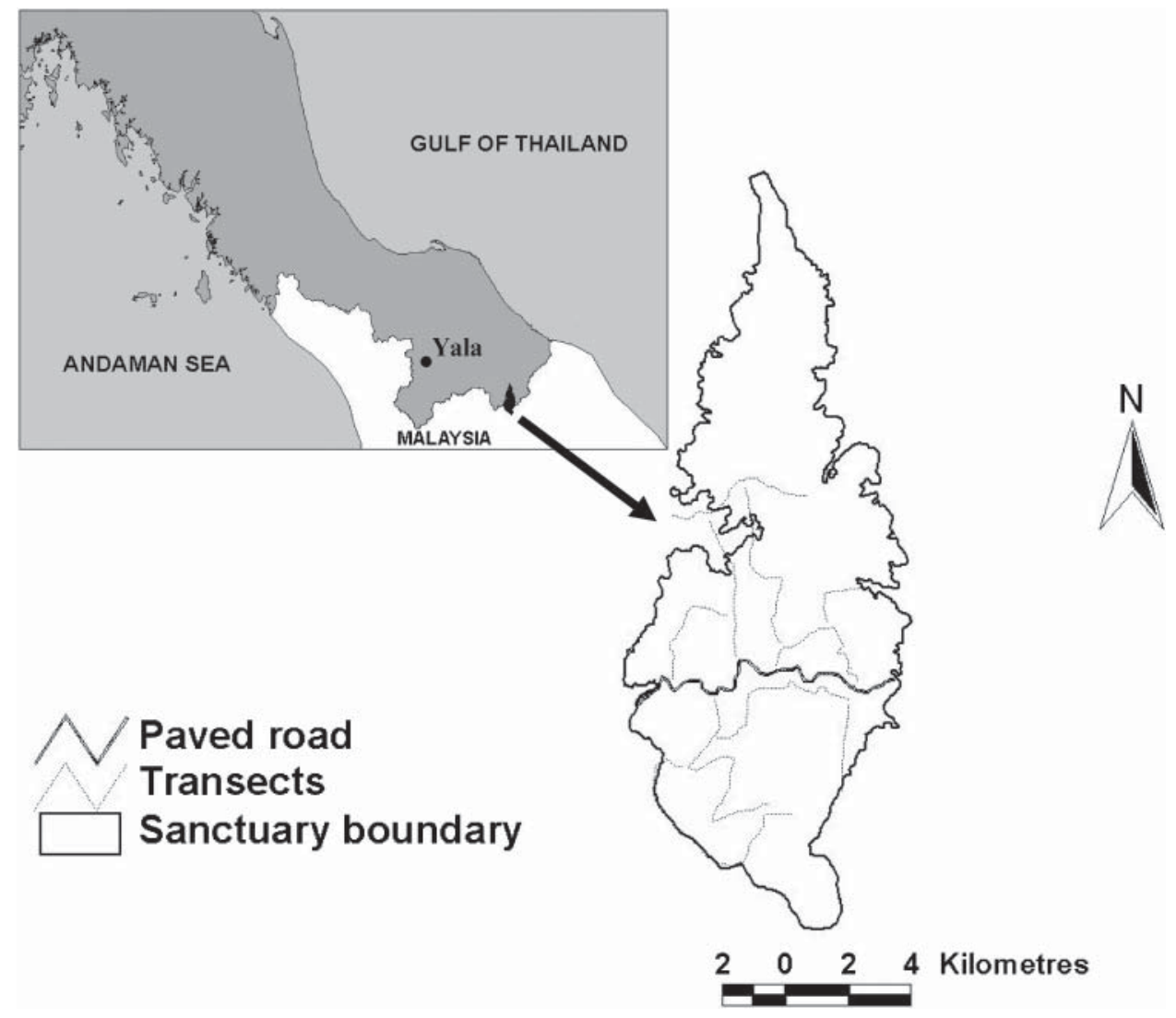

Figure 1. The Bala portion of the Hala-Bala Wildlife Sanctuary. Part of the paved road was also used as a transect and sections of some of the transects occur outside the sanctuary boundaries.

\section{Survey methodology}

We used variable-width line transect surveys to estimate the densities of the focal species following the methods of Bibby et al. (1992). Once per month, between January 2001 and April 2002, we surveyed 11 transects totalling $68 \mathrm{~km}$ in length. (The exception was the first survey period, which had to be spread over the period between the end of January and the beginning of March 2001 due to initial logistical problems.) The transects ranged from 3 to approximately $11.4 \mathrm{~km}$ in length and were $>200 \mathrm{~m}$ from each other to minimize double counting of individuals when transects were run simultaneously. All transects were surveyed between 14 and 16 times. The density of the vegetation and the steep terrain prevented us from creating straight transects, and therefore survey routes followed existing trails, including old logging roads and the one paved road (Figure 1 ). While surveys utilizing variable circular plots (e.g. Marsden 1999, Marsden and Pilgrim 2003) may be less likely to violate distance sampling assumptions and are easier to implement, they require a large number of points (>2000) for uncommon species, and typically do not work as well for highly mobile, relatively rare species (Lloyd et al. 1998). Although non-random selection of 
transect locations could potentially bias results, and therefore our estimates may be unrepresentative of Bala as a whole (Buckland et al. 2001), the home ranges of these birds are large $\left(>10 \mathrm{~km}^{2}\right)$ and they often fly high $(>50 \mathrm{~m})$ over the canopy, so that narrow trails and overgrown logging roads were likely to have only minimal impact on their behaviour. However, probability of detection may have been slightly higher along the paved road due to greater visibility. In addition, transects covered a sufficient portion of the study area to be representative of most of the sanctuary, except for the northernmost section which was largely unsurveyed (Figure 1). Transects were marked in the field every $100 \mathrm{~m}$ and surveyed using GPS to assist in estimating the closest approach distance of the birds to the transects. Surveys were carried out by three observers who had been working in the sanctuary for several weeks before the start of the study. During this time the authors trained the observers in species identification and visual and aural distance estimation by testing them and then confirming the distance to observed birds and other random objects with a tape measure. Observers were rotated among transects to reduce potential observer bias. Starting and ending points of transects were reversed on alternate surveys to avoid biases associated with time of day. Due to the length of the transects and the logistics of getting to starting locations, surveys ran throughout the day, with the majority of surveys conducted between o8hoo and I4hoo.

On each transect, observers recorded (I) focal species (and sex when possible), (2) number of individuals, (3) detection cue/activity (visual, vocal or flying), (4) location of the observer on the transect, (5) estimated distance between the observer and the focal species, (6) angle between the observer and the bird relative to the transect, and compass direction to estimate positions on GIS maps, and (7) other relevant information, for example the presence of a fruiting fig or other large fruiting tree species. Birds that were observed flying (i.e. those flying birds that were not seen leaving the area near transects) were recorded, but not used to estimate the density (following Lloyd et al. 1998).

\section{Analyses}

Density estimates were produced using the DISTANCE 4.0 program (Thomas et al. 2003). Because our transects utilized existing trails and therefore typically did not run straight, distances had to be recorded as the closest approach of the birds to the trails, following Hiby and Krishna (2001), rather than the standard perpendicular distances normally used for straight transects. We used GIS and GPS to estimate closest approach distances as birds and the trails were largely invisible beyond $30 \mathrm{~m}$. For software settings, we followed the recommendations of Buckland et al. (2001) and those used by others for estimating the densities of the same or similar species in the region (Kinnaird et al. 1996, Marsden 1999, Anggraini et al. 2000). Specifically, for all species, birds were entered as clusters and distance data were grouped automatically by the software. Both aural and visual observations were combined (following Kinnaird et al. 1996, Marsden 1999, Anggraini et al. 2000). For the aural detections we used the mean cluster size from our visual observations as the observed cluster size for data input. For the model definition properties, cluster size was derived from the mean observed cluster size, otherwise size-bias regression (regression of log cluster size against estimated detection function $\mathrm{g}[\mathrm{x}]$ ) was used when the regression was 
significant at $\alpha=$ o.15. Models were fitted using the automated sequential selection and the Akaike's Information Criteria (AIC) stopping rule. A wide variety of key functions and series expansions were examined to fit detection functions to the data. We tested primarily uniform, half-normal and hazard key functions with either the cosine, polynomial or hermite adjustment terms. The shape of our data typically did not require the use of the negative exponential key function. We also tested a variety of truncation distances and found that truncating observations beyond $150 \mathrm{~m}$ usually gave the best model fits, but for some species we utilized observations up to $400 \mathrm{~m}$ away from the transects. We chose truncation distances based on those that provided the lowest coefficient of variation of the density estimate (following Kinnaird et al. 1996), and then using the lowest AIC function when selecting the best model among those with the same truncation distances and other input parameters, following Buckland et al. (2001).

For species for which there were insufficient observations to estimate densities from distance sampling, we incorporated simple spot-mapping methods and GIS maps of known observations using ArcView (ESRI 1997) in which we estimated a minimum density of individuals present in the area surveyed.

\section{Results}

A total of 1,261 observations of the nine species was obtained during the study period. The majority of the observations were aural rather than visual $(75.7 \%$ vs $18.6 \%$, and $5.8 \%$ observed flying). Due to inaccuracies in using the GPS for marking locations and estimating distances to the curving transects, only 937 of the above observations were usable for the analysis.

The number of observations each month varied considerably during the course of the year. Ignoring the first survey period, which was spread over 3 months (JanuaryMarch), the total number of birds observed ranged from 98 during March 2001 to 205 in February 2002. Because the number of observations for each species was too small in any given month to estimate densities using distance sampling, we used simple count trends to examine monthly variation. There was little correlation in the number of observations among the different species during the year (Figure 2), such that there was no clear trend to suggest in which months surveys might be conducted most efficiently. However, the number of monthly observations of Rhinoceros and Helmeted Hornbills were moderately positively correlated during the study period (Pearson $r_{\mathrm{p}}=0.60, P<0.05$ ), while the number of monthly observations of Wrinkled and Great Hornbills were negatively correlated $\left(r_{\mathrm{p}}=-0.55, P<0.05\right)$. There was no significant correlation between the total number of observations and the number of visual observations, nor was there a significant correlation between total monthly rainfall and the total number of monthly observations $\left(r_{\mathrm{p}}=-0.13\right.$ and $r_{\mathrm{p}}=-0.19$, $P>0.05$ respectively).

Density estimates using distance sampling were possible for seven of the nine species. Insufficient sample sizes for the remaining two (Plain-pouched Hornbill and Black Hornbill) were presumably the result of low densities, and densities had to be estimated via simple spot mapping techniques described above. Densities ranged from 2.69 individuals $/ \mathrm{km}^{2}$ for Rhinoceros Hornbill to approximately 0.07 individuals $/ \mathrm{km}^{2}$ for Black Hornbill (Table 1 ). 


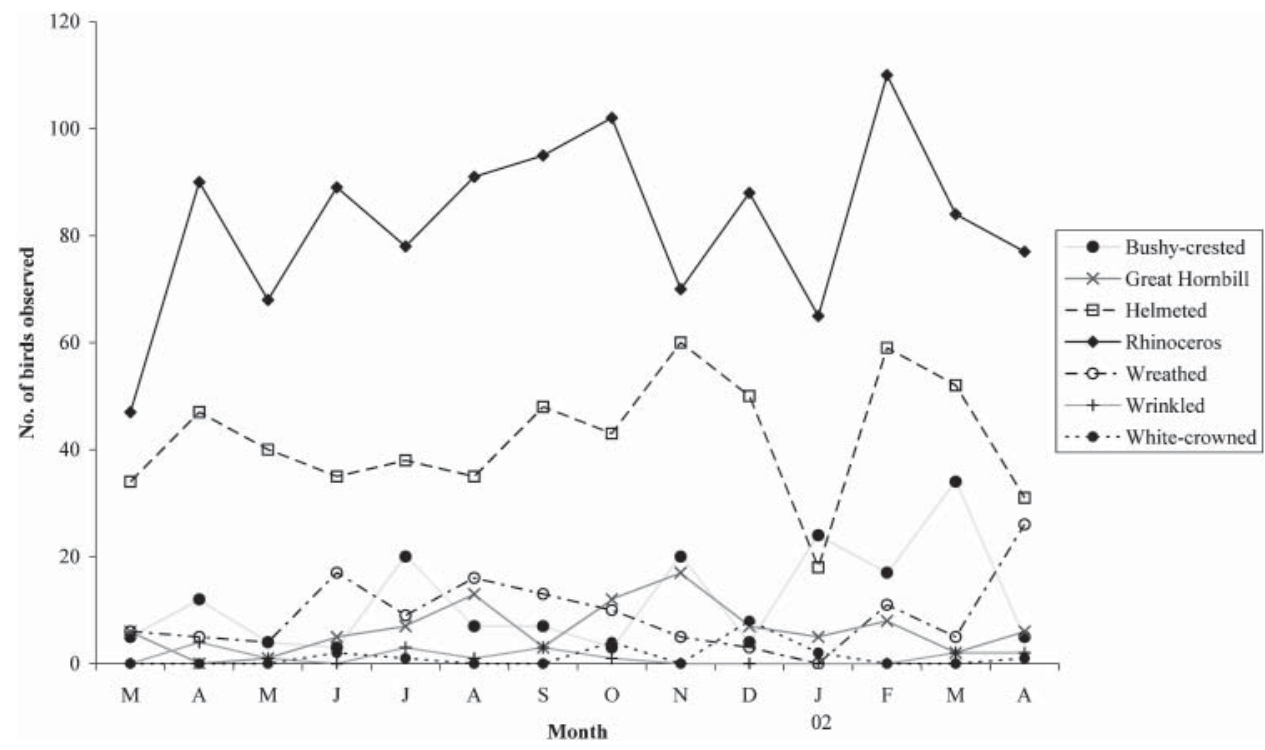

Figure 2. Number of birds observed of the seven most common hornbill species in the Hala-Bala Wildlife Sanctuary between March 2001 and April 2002.

Table 1. Summary of density estimates for nine hornbill species in Bala Wildlife Sanctuary based on 16 months of observations (February 2001 to April 2002)

\begin{tabular}{|c|c|c|c|c|c|c|c|}
\hline \multirow[t]{2}{*}{ Species } & \multirow{2}{*}{$\begin{array}{l}\text { Average } \\
\text { group size }\end{array}$} & \multirow{2}{*}{$\begin{array}{l}\text { No. of clusters } \\
\text { used for } \\
\text { analysis }(n)\end{array}$} & \multirow{2}{*}{$\begin{array}{l}\text { Probability } \\
\text { of detection }\end{array}$} & \multicolumn{4}{|c|}{ Density (individuals/ $\mathrm{km}^{2}$ ) } \\
\hline & & & & Estimate & $\begin{array}{l}\text { Lower } \\
95 \% \\
\text { CI }\end{array}$ & $\begin{array}{l}\text { Upper } \\
95 \% \\
\text { CI }\end{array}$ & $\begin{array}{l}\% \\
\mathrm{CV}\end{array}$ \\
\hline Rhinoceros Hornbill & 2.8 & 210 & 0.67 & 2.69 & 1.99 & 3.64 & 0.14 \\
\hline Great Hornbill & 1.8 & 27 & 0.56 & 0.12 & 0.08 & 0.19 & 0.21 \\
\hline Helmeted Hornbill & 2.9 & 123 & 1.00 & 1.21 & 0.81 & 1.82 & 0.19 \\
\hline Black Hornbill & 1.5 & $-{ }^{b}$ & - & 0.07 & - & - & - \\
\hline Bushy-crested Hornbill & 5.2 & 31 & 0.37 & 0.64 & 0.32 & 1.28 & 0.36 \\
\hline White-crowned Hornbill & 1.8 & 6 & 1.00 & 0.08 & 0.03 & 0.24 & 0.40 \\
\hline Wrinkled Hornbill & 1.5 & 9 & 0.63 & 0.08 & 0.04 & 0.13 & 0.26 \\
\hline Wreathed Hornbill & 2.0 & 33 & 0.30 & 0.69 & 0.40 & 1.18 & 0.26 \\
\hline Plain-pouched Hornbill & 2.0 & - & - & 0.09 & - & - & - \\
\hline Total & & & & 5.67 & & & \\
\hline
\end{tabular}

$\mathrm{CI}$ indicates the $95 \%$ confidence interval around the estimates and \%CV the coefficient of variation of the estimate.

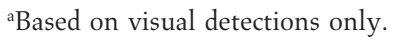

${ }^{b}$ Estimates based on spot mapping as there were an insufficient number of detections to use with the distance analysis.

Plain-pouched Hornbills were observed on six different occasions, with all the observations occurring between March and August, suggesting that they were present in the breeding season in Bala (February-July) but perhaps moved out of the area during the non-breeding season. The maximum number of individuals observed at any one time was four. For the Black Hornbill, only three individuals were observed in total, with at least one pair, and one additional male in widely separated locations. 
For the seven species in which density estimation was possible, the coefficient of variation was negatively correlated with sample size (Spearman rank correlation, $r_{\mathrm{s}}=-0.77, P<0.05$ ), and only became large when the sample size was small (Table 1 ). Furthermore, although we were unable to independently verify the accuracy of our estimates, we found that even with as few as nine observations it was possible to obtain modest levels of precision similar to previous studies using distance sampling (e.g. Marsden 1999, Nelson and Fancy 1999).

\section{Discussion}

One method of assessing the relative conservation value of Bala is to compare densities of species found here with densities of the same species reported elsewhere, assuming that a higher density implies better quality habitat (e.g. Ortega and Capen 1999). Overall, while precise comparisons were generally not possible due to different sampling methodologies, Bala appeared to support a lower overall density of hornbills than elsewhere in the region (Table 2). Of the seven sites for which we had data, only one reported a similar density to Bala (Whitmore 1984, cited in Kinnaird et al. 1996) while the remaining sites had 1.6-5.2 times greater densities. At the species level, as indicated above, no previous density estimates for Plain-pouched Hornbill were available for comparison, while the densities of two species (Rhinoceros and Helmeted Hornbill) appeared to be similar to those reported elsewhere; densities of the remaining six species (Great, Black, White-crowned, Wrinkled, Bushy-crested and Wreathed Hornbill) were generally lower, but the reasons for the lower density appeared to vary among species (see below).

Our data suggest that Plain-pouched Hornbill, the most threatened of the species surveyed, use Bala for breeding, but may move out of the sanctuary during the nonbreeding season, perhaps joining large nomadic flocks previously seen in the region (Ho and Sutari 2000, BirdLife International 2001). This species is also a lowland specialist, and a highly localized breeder, which may account for its low breeding densities (Rasmussen 2000), but without comparisons with other studies it is difficult to assess the value of Bala to this species. Current data suggest that Bala is near to, or at the edge of, a significantly larger population (flocks $>900$ birds) which have been observed further to the west in Yala, Thailand and particularly to the south-west in northern Perak, Malaysia thought to be the "global stronghold" of the species (Ho and Sutari 2000, BirdLife International 2001). However, almost nothing is known about these populations, and our study reinforces the point that more research needs to be focused on the ecology and distribution of this species along the Thai-Malaysia border.

For the two most abundant hornbills found in the study area, Rhinoceros and Helmeted, densities were remarkably similar to sites further south in Malaysia and Indonesia (Table 2). Rhinoceros Hornbill in particular seems to show relatively little variation in density throughout its range, with the exception of one isolated forest patch where 20 birds $/ \mathrm{km}^{2}$ were recorded (Johns 1988, cited in Kemp 1995).

As regards possible explanations for the lower than expected densities of the other six species, McConkey and Chivers (2004) suggested several factors including hunting (for hornbills this could also include chick poaching: Poonswad et al. 2004), forest isolation, fruit supplies and lack of specific habitat(s) to account for low densities of 


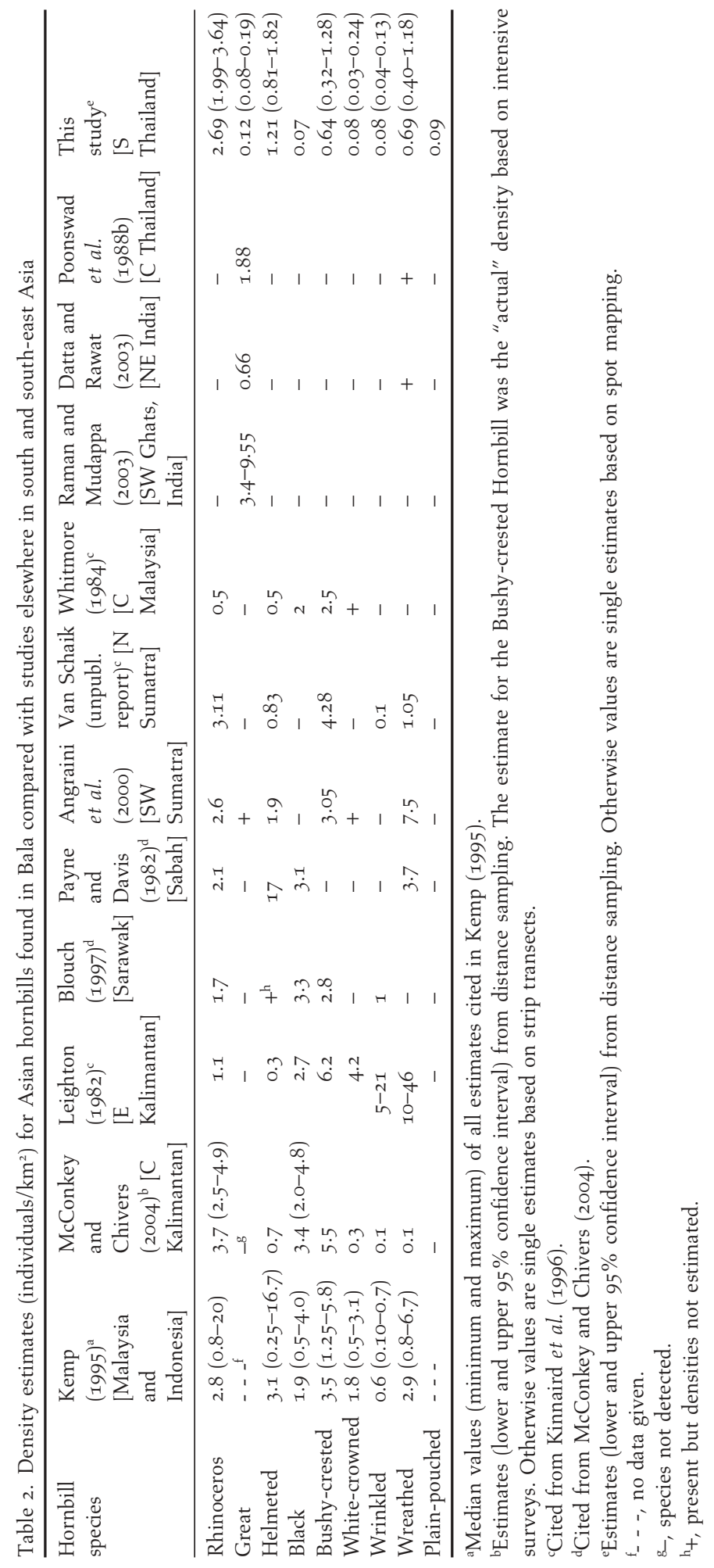


mammals and hornbills in their site in Central Kalimantan. In our study, we suggest that interspecific competition could be an additional factor responsible for reduced densities of some species (see below). Of these five factors, hunting/poaching did not appear to be significant due to their relatively moderate levels, although these have yet to be quantified. Additionally, even if hunting/poaching were more serious, it seems unlikely that they would have affected the small-bodied Bushy-crested and White-crowned Hornbill more than the larger-bodied, relatively conspicuous species such as Rhinoceros and Helmeted Hornbill.

Great Hornbill density was considerably lower than reported from central Thailand (based on nest densities and direct counts, Poonswad et al. 1988b) and India (based on variable-width line transects, Raman and Mudappa 2003; and nesting densities, Datta and Rawat 2003). The core range of the Great Hornbill probably lies in more seasonal Indochinese forest to the north of the Kangar-Pattani phytogeographic transition separating the more seasonal Thai-Burmese forest to the north, from perhumid Malaysian floristic formation rainforest (van Steenis 1950, Whitmore 1984). This suggests that this species would probably be competitively at a disadvantage in the Malaysian-type rainforest of Bala. Presumably lower densities in this case are the result of a combination of factors including the absence of particular habitat structure and food resources, as well as increased competition from the closely related Rhinoceros Hornbill (Emlen et al. 1986). Future studies focusing on details of these factors may provide additional insight as to how both species might respond to a variety of human disturbances.

Black Hornbills appear to be tightly associated with extreme lowland $(<200 \mathrm{~m})$ habitats, including peat swamp forest (Kemp 1995, Wells 1999, Robson 2002) which are largely missing from Bala and now most of southern Thailand, and this may account for their rarity.

Reasons for the scarcity of the White-crowned Hornbill are far less clear. Although probably uncommon throughout its range, it appears to be more common in midelevation seasonal evergreen forest compared with non-seasonal lowland habitats. It is regularly recorded up to $800 \mathrm{~m}$ (Kemp 1995, Wells 1999) and at least occasionally as high as 1,680 $\mathrm{m}$ (Kemp 1995). It is considered mainly carnivorous (Johns 1987 cited in Kemp 1995), but no quantitative dietary study has been published on this species in contrast to other hornbills (e.g. Poonswad et al. 1988a, 2004), and therefore it is unknown as to whether or not its diet is related to its low abundance at Bala.

With the exception of one study in E. Kalimantan (Leighton 1982), Wrinkled Hornbill appears to occur at relatively low densities throughout its range, typically $<1$ individual $/ \mathrm{km}^{2}$ and perhaps often considerably lower than this. Thus, while densities at Bala were only 0.08 individuals $/ \mathrm{km}^{2}$, three of the eight other sites where density estimates were available also reported similarly low values (Table 2). In addition, like the Black Hornbill, it is associated with lowland habitats below $500 \mathrm{~m}$ (Wells 1999), and probably more typically found in forests below $250 \mathrm{~m}$ (Kemp 1995).

The relatively low density of Bushy-crested Hornbills was probably the most surprising, given our moderate to high density estimates of the larger-bodied Rhinoceros Hornbill and Helmeted Hornbill. For example, in the seven sites for which we have reasonably complete data, on average approximately $30 \%$ of the individuals of the entire hornbill community were of this species, while in Bala it was only $11 \%$. It is possible that habitat factors, and a lower availability of fruiting trees (Anggraini et al. 
2000) or perhaps more specifically a scarcity of lipid-rich fruit, which it is known to prefer (Leighton and Leighton 1983 cited in Kemp 1995), may have contributed to its lower abundance. In addition this species had the strongest preference for closed canopy forest and the strongest avoidance of disturbed areas compared with Rhinoceros, Helmeted and Wreathed Hornbills in a site in south-western Sumatra (Anggraini et al. 2000) and was thought to prefer dense forests with a well-developed mid-canopy (van Marle and Voous 1988 cited in Anggraini et al. 2000, Kemp 1995). This also suggests that there may be some inherent difference in the forest structure, perhaps exacerbated by the previous logging, that renders Bala less suitable for this species. Radio-telemetry studies in conjunction with vegetation and food availability surveys would probably be required at sites with different densities to test the relationship between density, home range size, food availability and forest structure.

Although they appear to be relatively more tolerant of disturbance compared with Rhinoceros, Helmeted and Bushy-crested Hornbills (Anggraini et al. 2000), Wreathed Hornbills, which are known to range widely during the breeding ( 10.0 $\left.\mathrm{km}^{2}\right)$ and non-breeding seasons $\left(\sim 28 \mathrm{~km}^{2}\right)$ (Poonswad and Tsuji 1994), may have been limited by the relatively small size of the Bala sanctuary (111.5 $\left.\mathrm{km}^{2}\right)$.

In summary, while hornbill diversity at Bala is high, and offers reasonably good habitat for Rhinoceros and Helmeted Hornbill, habitat quality for Great, Black, White-crowned, Wrinkled, Bushy-crested and Wreathed Hornbill seems to be only fair to marginal. Although the density of Plain-pouched Hornbills appeared to be low, the value of Bala to this hornbill, the most threatened species studied here, remains unclear as this was the first published breeding density estimate as far as we are aware. However, it is clear that the border region near Bala is an important global population centre for Plain-pouched Hornbills and should be given higher priority for further study. Overall, reasons for lower densities of some species were possibly the result of scarcity of lowland habitat, habitat isolation, a lower abundance of lipidrich food resources and interspecific competition, but each factor requires further investigation. In addition, we strongly encourage the use of sampling methods that utilize detection probabilities, to make comparisons among sites, habitats and levels of disturbance easier and more robust. Finally, although using existing trails does present significant methodological problems, our experience suggests that where straight transects are likely to be impractical, using curving transects is feasible and may provide a greater number of detections than point transects.

\section{Acknowledgements}

We are grateful to P. Round, M. Kinnaird, S. Browne and an anonymous reviewer for comments on the manuscript and to P. Poonswad for much helpful advice regarding the biology of hornbills including important references. Thanks also go to A. Datta, D. Mudappa, T. Raman and G. Rawat for providing copies of their manuscripts in press, and to S. Strindberg, J. Nichols, and L. Thomas in particular, for technical references and advice on distance sampling. Finally, many thanks to P. Wongprom, R. Surai and S. Suvanapong and their colleagues for their hard work and enthusiasm during data collection and data entry, as well as their logistical support for G. G. in Bala. Partial funding of this work was provided by the Thai Biodiversity Research and Training Program, grant BRT_143017. 


\section{References}

Anggraini, K., Kinnaird, M. and O'Brien, T. (2000) The effects of fruit availability and habitat disturbance on an assemblage of Sumatran hornbills. Bird Conserv. Int. 10: 189-202.

Bibby, C. J., Burgess, N. D. and Hill, D. A. (1992) Bird Census Techniques. London: Academic Press.

BirdLife International (2001) Threatened Birds of Asia: The BirdLife International Red Data Book. Cambridge, U.K.: BirdLife International.

Buckland, S. T., Anderson, D. R., Burnham, K. P., Laake, J. L., Borchers, D. L. and Thomas. L. (2001) Introduction to Distance Sampling: Estimating Abundance of Biological Populations. Oxford: Oxford University Press.

Datta, A. and Rawat, G. S. (2003) Foraging patterns of sympatric hornbills in the non-breeding season in Arunachal Pradesh, north-east India. Biotropica 35: 208-218.

Emlen, J. J., Delong, M. J., Jaeger, M. J., Moermond, T. C., Rusterholtz, K. A. and White, R. P. (1986). Density trends and range boundary constraints of forest birds along a latitudinal gradient. Auk 103: 781-803.

ESRI. (1997) ArcView, version 3.oa. Redlands, CA: Environmental Systems Research Institute.

Fancy, S. and Sauer, J. (2000) Recommendations for inventorying and monitoring landbirds in national parks. http://www.nature.nps.gov/im/monitor/npsbird.doc. Accessed I4 May 2003.

Hiby, L. and Krishna, M. B. (2001) Line transect sampling from a curving path. Biometrics 57: $727-731$.

Ho, H. C. and Sutari, S. (2000) Observations of Plain-pouched Hornbills Aceros subruficollis in Tasek Temengor, Peninsular Malaysia. Forktail 16: 65-67.

IUCN (2004) 2004 Red List of threatened species. Gland, Switzerland: IUCN. http://www. http: //www.redlist.org. Accessed 31 March 2005.

Johns, A. D. (1987) The use of primary and selectively logged rainforest by Malaysian hornbills (Bucerotidae) and implications for their conservation. Biol. Conserv. 40: 179-190.

Johns, A. D. (1988) Long-term effects of selective logging operations on Malaysian wildlife. II. Case studies in the Ulu Segama Forest Reserve, Danum Valley and Tabin conservation areas, Sabah, east Malaysia. Final report to the Danum Valley Management Committee, Sabah Foundation, and the Socioeconomic Research Unit of the Prime Minister's Department. Unpublished manuscript.

Karanth, K. U. and Nichols J. D. (1998) Estimation of tiger densities in India using photographic captures and recaptures. Ecology 79: 2852-2862.

Kemp, A. C. (1995) Bird Families of the World: The Hornbills, Bucerotiformes. Oxford: Oxford University Press.

Kinnaird, M. F., O'Brien, T. G. and Suryadi, S. (1996) Population fluctuation in Sulawesi red-knobbed hornbills: tracking figs in space and time. Auk 113: 431-440.

Lambert, F. R. and Collar, N. J. (2002) The future for Sundaic lowland forest birds: long-term effects of commercial logging and fragmentation. Forktail 18: 127-146.

Leighton, M. (1982) Fruit resources and patterns of feeding, spacing and grouping among sympatric Bornean hornbills (Bucerotidae). PhD dissertation, University of California, Davis.

Leighton, M. and Leighton, D. R. (1983) Vertebrate responses to fruiting seasonality within a Bornean rain forest. In S. L. Sutton, T. C. Whitmore and A. C. Chadwick, eds. Tropical Rain Forest: Ecology and Management. Oxford: Blackwell Scientific (British Ecological Society, special publication no. 2).

Lekagul, B. and Round, P. D. (1991) Birds of Thailand. Bangkok, Thailand: Saha Karn Bhaet.

Lloyd, H., Cahill, A., Jones, M. and Marsden, S. (1998) Estimating bird densities using distance sampling. In C. Bibby, M. Jones and S. Marsden, eds. Expedition Field Techniques. London: Royal Geographical Society.

Marsden, S. J. (1999) Estimation of parrot and hornbill densities using a point count distance sampling method. Ibis 141: 377-390. 
Marsden, S. J. and Pilgrim, J. D. (2003) Factors influencing the abundance of parrots and hornbills in pristine and disturbed forests on New Britain, PNG. Ibis 145: 45-53.

McConkey, K. R. and Chivers, D. J. (2004) Low mammal and hornbill abundance in the forests of Barito Ulu, Central Kalimantan, Indonesia. Oryx 38: 439-447.

Nelson, J. T. and Fancy, S. G. (1999) A test of the variable circular-plot method where exact density of a bird population was known. Pacific Conserv. Biol. 5: 139-143.

Norvell, R. E., Howe, F. P. and Parrish, J. R. (2003) A seven-year comparison of relativeabundance and distance-sampling methods. Auk 120: 1013-1028.

OEPP (undated) Office of Environmental Policy and Planning. http://arcbc.org/cgi-bin/ oepp.exe. Accessed 24 June 2005.

Ortega, Y. K. and Capen, D. E. (1999) Effects of forest roads on habitat quality for ovenbirds in a forested landscape. Auk 116: 937-946.

Poonswad, P., ed. (1998) The Asian Hornbills: Ecology and Conservation. Bangkok, Thailand: Biodiversity Research and Training Program (Thai Studies in Biodiversity, no. 2).

Poonswad, P. and Tsuji, A. (1994) Ranges of males of the Great Hornbill Buceros bicornis, Brown Hornbill Ptilolaemus tickelli and Wreathed Hornbill Rhyticeros undulates in Khao Yai National Park, Thailand. Ibis 136: 79-86.

Poonswad, P., Tsuji, A., Jirawatkavi, N. and Chimchome, V. (1988a) Some aspects of food and feeding ecology of sympatric hornbill species in Khao Yai National Park, Thailand. In P. Poonswad, ed. The Asian Hornbills: Ecology and Conservation. Bangkok, Thailand: Biodiversity Research and Training Program (Thai Studies in Biodiversity, no. 2).

Poonswad, P., Tsuji, A., Liewviriyakit, R. and Jirawatkavi, N. (1988b) Effects of external factors on hornbill breeding and population. In B. L. Dresser, R. W. Reece and E. J. Maruska, eds. Proceedings of the 5th World Conference on Breeding Endangered Species in Captivity. Cincinnati, OH: Cincinnati Zoo and Botanical Garden.

Poonswad, P., Tsuji, A. and Jirawatkavi, N. (2004) Estimation of nutrients delivered to nest inmates by four sympatric species of hornbills in Khao Yai National Park, Thailand. Ornithol. Sci. 3: 99-112.

Raman, T. R. S. and Mudappa, D. (2003) Correlates of hornbill distribution and abundance in rainforest fragments in the southern Western Ghats, India. Bird Conserv. Int. 13: 199-212.

Rasmussen, P. C. (2000) A review of the taxonomy and status of the Plain-pouched Hornbill Aceros subruficollis. Forktail 16: 83-91.

Robson, C. (2002) Birds of Thailand. Princeton, NJ: Princeton University Press.

Round, P. D. (1988) Resident Forest Birds in Thailand: Their Status and Conservation. Cambridge, U.K.: International Council for Bird Preservation (Monograph no. 2).

Thomas, L., Laake, J. L., Strindberg, S., Marques, F. F. C., Buckland, S. T., Borchers, D. L., Anderson, D. R., Burnham, K. P., Hedley, S. L., Pollard, J. H. and Bishop, J. R. B. (2003) DISTANCE 4.I, release 2. Research Unit for Wildlife Population Assessment, University of St. Andrews, U.K. http://www.ruwpa.st-and.ac.uk/distance/

van Marle, J. G. and Voous, K. H. (1988) The Birds of Sumatra. London: British Ornithologists' Union (Check-list 10).

van Steenis, C. G. G. J. (1950) The delimitation of Malesia and its main geographical divisions. Flora Malesiana Series 1, 1: LXX-LXXV.

Wells, D. R. (1999) The Birds of the Thai-Malay Peninsula. Vol. 1: Non-Passerines. London: Academic Press.

Whitmore, T. C. (1984) Tropical Rainforests of the Far East. Second Edition. Oxford: Clarendon Press.

\section{GEORGE A. GALE}

King Mongkut's University of Technology Thonburi, School of Bioresources \& Technology, Division of Natural Resources Management, 83 Moo. 8 Thakham, Bangkhuntien, Bangkok 10150, Thailand. E-mail: george.and@kmutt.ac.th 
SIRIPORN THONGAREE

Bala-Hala Wildife Research Station, National Park and Wildlife Research Division, Department of National Parks, Wildlife and Plant Conservation, Phaholyothin Road, Chatuchak, Bangkok 1090o, Thailand.

Received 17 September 2004; revision accepted 24 May 2005 